\title{
Comparative Study of Sub grade Soil Strength Estimation Models Developed Based on CBR, DCP and FWD Test Results
}

\author{
Dr. R. Srinivasa Kumar ${ }^{1}$, Alhammadi Shabbab Ajmi ${ }^{2}$, Bhasker Valkati ${ }^{3}$ \\ Assistant Professor, Civil Engineering Department, Osmania University, Hyderabad, India ${ }^{\mathbf{1}}$ \\ Associate Professor and Dean, Civil Engineering Department, Shaqra University, Dawadmi, KSA ${ }^{2}$ \\ Lecturer, Civil Engineering Department, Shaqra University, Dawadmi, KSA ${ }^{3}$
}

\begin{abstract}
Sub grade soil strength is an essential input for design of pavements and overlays. Many models are available for determination of subgrade soil strength. Subgrade soil strength in terms of elastic modulus value is used in Mechanistic-Empirical methods and CBR value is used in empirical methods of design. Both the parameters can be used for structural evaluation of flexible pavement. Determination of elastic moduli values of pavement layers by backcalculation of deflections measured using Falling Weight Deflectometer (FWD) is a widely used scientific method. However, extensive use of FWD for large scale evaluation of in-service pavements is not feasible, especially for low volume roads, unimportant roads and roads in developing and under developed countries. In the present investigation, an attempt has been made to develop relationships that can be used to estimate subgrade soil strength in terms of elastic modulus and CBR values using in-situ test results of Dynamic Cone Penetrometer (DCP). As DCP is a portable and low-cost equipment used for quick evaluation of unbound granular and subgrade soil. Comparative studies are also carried out with similar models available from the literature review.
\end{abstract}

Keywords: Falling weight Deflectometer (FWD), Back-calculated subgrade modulus, California Bearing Ratio (CBR), Dynamic Cone Penetrometer (DCP) and Regression Models.

\section{INTRODUCTION}

Recent trend of flexible pavement design is based on Penetrometer was developed by Scala (1956) in Australia. mechanistic and empirical (M-E) methods. The M-E It was used for determination of in-situ CBR of cohesive methods use elastic moduli values and the empirical subgrade soils. The Scala Penetrometer consists of about 9 methods use CBR values of subgrade soil. The task of $\mathrm{kg}$ hammer which drops from $510 \mathrm{~mm}$ height through a selecting appropriate values of subgrade strength for the vertical guide rod. The hammer impact energy is analysis of new as well as in-service pavements has been ultimately applied on to a cone (having apex angle $30^{\circ}$ ) drawing the attention of pavement researchers for a fitted at bottom end of the guide rod.

number of years.

Later, a similar tool like DCP was developed by van Assessment of elastic moduli of granular and subgrade soil Vuuren (1969). It consists of a $10 \mathrm{~kg}$ hammer which drops by using Falling Weight Deflectometer (FWD) or freely from $460 \mathrm{~mm}$ height. The impulse force is applied laboratory testing are very popular methods but they could on to a cone having $30^{\circ}$. He has developed a relationship be costly procedures for evaluation of unimportant or low between the DCP test results and CBR values of subgrade traffic volume roads, in developing and under developed soil.

countries. Due to this reason, Dynamic Cone For rapid evaluation of flexible pavements a DCP was Penetrometer (DCP) test has been extensively used by used by the Transvaal Roads Department of South Africa several countries around the globe for quick determination in 1973 (Kleyn 1975). The DCP consisted of $8 \mathrm{~kg}$ hammer of an index value which represent the strength of which drops from height of $574 \mathrm{~mm}$. The cone's apex compacted unbound granular and soil layers with angles considered were $30^{\circ}$ and $60^{\circ}$ and a comparative reasonable accuracy at low cost.

In the present investigation, an effort has been made to develop regression models by correlating the results obtained from the evaluation of the subgrade soil of pavements using test results of CBR, Dynamic Cone Penetrometer (DCP) and Falling Weight Deflectometer (FWD).

\section{HISTORICAL DEVELOPMENT OF DCP} study was carried out between the DCP test results (Kleyn et al 1982). Another report (Kleyn and Savage, 1982) reveals that, several investigations were made on subgrade tested with DCP using $8 \mathrm{~kg}$ hammer dropped from height of $574 \mathrm{~mm}$ and with the cone's apex angle as $60^{\circ}$.

\section{WORKING PRINCIPLE OF DCP}

The salient features of the widely used manually operated DCP are presented in Figure 1. The resistance offered by The first Dynamic Cone Penetrometer (DCP), which is similar the one available now, known as Scala

the compacted granular/soil layer to penetration of a standard cone having $20 \mathrm{~mm}$ diameter and apex angle $60^{\circ}$ 
driven by a $8 \mathrm{~kg}$ hammer dropped from a height of $575 \mathrm{~A}$. $\mathrm{mm}$, is recorded as average penetration per blow (IRC: SP:72 2007).

The average penetration of the cone per blow is reported in as an index value and it may be represented in many forms viz. DCP index (DCPI), DCP, penetration rate (PR), penetration index $(\mathrm{PI}), \mathrm{DCP}_{\theta}{ }^{\circ}$; or Number of blows required to penetrate a given thickness of layer as (DCPN), $\mathrm{N}_{\mathrm{DCP}}$, Blow Rate (BR) and DCP Structural Number (DSN). In this paper, the cone's average penetration per blow (in mm/blow) is denoted as $\mathrm{DCP}_{\theta}{ }^{\circ}$, where, $\theta^{\circ}$ denotes apex angle of the cone.

During the cone penetration, the material shear strength is mainly accrued due to resistance offered by the shear displacement of soil particles. A smaller value of $\mathrm{DCP}_{60}{ }^{\circ}$ indicates harder material and vice versa.

\section{A. Testing with DCP}

To begin with the testing procedure, initial reading on the DCP scale should be noted while holding the rod vertical and the cone in contact with surface of compacted soil to be tested. While one person holds the DCP handle, another person should lift the hammer to the predetermined height (i.e. $575 \mathrm{~mm}$ ) and allow it to drop freely on to the anvil. Cumulative penetration values of the cone should be noted for each blow. Generally, the DCP testing should be stopped when the cone penetration is not more than $1 \mathrm{~mm}$ per blow since the cone may encounter a rock, gravel larger than $20 \mathrm{~mm}$ size or hard strata. After the DCP test is over, the cone-rod should be extracted out and the soil sample may be collected for conducting other tests in laboratory.

An extension rod of additional length of $1000 \mathrm{~mm}$ may be used in place of the standard penetrating rod where it is necessary to test the deep soil (Livneh and Livneh, 1994).

A study was conducted by Livneh (1991) for determining the change in rate of penetration due to change in the cone apex angle from $30^{\circ}$ to $60^{\circ}$ and suggested the following relationship to convert DCP index value (in $\mathrm{mm} / \mathrm{blow}$ ) in terms of the other.

$$
\mathrm{DCP}_{30^{\circ}}=0.006+1.092 \mathrm{DCP}_{60^{\circ}}
$$

The DCP test can also be conducted in a laboratory on remolded material compacted in a steel mould which significantly eliminates the effect of confinement and such test can also be carried out as a prototype model (Ayers et al, 1989).

\section{REVIEW OF LITERATURE}

In different parts of the world, several researchers (De Villiers 1980; Livneh and Ishai 1987; Pen 1990; Chai and Roslie 1998; Chen and Latorella 1999; Livneh et al 2000; Roy 2007) have estimated strength properties of granular and subgrade soils by correlating DCP test results with standard test parameters. Such relationships can be used to convert the $\mathrm{DCP}_{\theta}{ }^{\circ}$ value to different strength parameters such as CBR, elastic modulus and other standard test values. The following paragraphs briefly present these relationships.

\section{Relationships between $\mathrm{DCP}_{\theta}{ }^{\circ}$ and $\mathrm{CBR}$ Values}

Several relationships are available to convert values of $\mathrm{DCP}_{\theta}{ }^{\circ}$ to CBR (Table 1). Such varieties of relationships do exist since large strain penetration takes place during testing of compacted soil by both the tests. A few salient details of different investigations made for development of the relationships (Table 1) are given below.

- Development of Scala Penetrometer (1956) for estimation of in-situ CBR of cohesive soils has led to development of the present version of DCP.

- Scala (1956) and Kleyn (1975) initially identified straight line relationship between the $\mathrm{DCP}_{\theta}{ }^{\circ}$ and CBR values plotted on log-log chart.

Laboratory CBR values were used for development of the US Corps of Engineer's relationship (Webster et al 1992). Many $\mathrm{DCP}_{\theta}{ }^{\circ}$ to $\mathrm{CBR}$ relationships developed by different researchers around the globe were considered in this study and they were found to be in close agreement with the relationship developed by Webster et al (1992). Therefore, this relationship has been widely used by several researchers (Livneh 1995; Siekmeier et al 2000 and Chen et al 2001).

Ese et al (1994), extensively evaluated 23 granular base courses in Norway and correlated laboratory $\mathrm{CBR}$ and $\mathrm{DCP}_{\theta}{ }^{\circ}$ values. They reported that, (i) difference in confining pressure in CBR mould and prevailing in-situ condition was accounted in development of the relationship and (ii) suggested that, a critical stability value of $2.6 \mathrm{~mm} / \mathrm{blow}$ may be taken for gravel base.

Nazzal (2003), conducted many laboratory CBR and field DCP tests on compacted granular materials, clay and soils stabilized. During the laboratory CBR testing, the moisture content and density were maintained similar to in-situ condition. He reported that, by using the equation (No.15), the estimated CBR values were well matching with the values obtained by equation (No. 10) (Webster et al 1992), when the $\mathrm{DCP}_{60}{ }^{\circ}$ value is greater than $20 \mathrm{~mm} / \mathrm{blow}$.

\section{B. Relationships between $\mathrm{DCP}_{\theta}{ }^{\circ}$ and FWD Back- calculated Subgrade Modulus Values}

Elastic moduli of pavement layers are essential inputs required in the mechanistic design of new pavements and for the estimation of the remaining life of in-service pavements. Towards this aim, selection of appropriate values of base and subgrade layer moduli for the analysis of new as well as in-service pavements is most critical issue concerning the pavement/soil researchers. To achieve this objective, several researchers in different countries have developed the following relationships between back-calculated subgrade moduli and DCP index values. Such relationships can be re-used where routine evaluation of pavement by FWD is not feasible for low traffic volume roads.

- Pen (1990) developed the following equations based on field DCP values. 
International Advanced Research Journal in Science, Engineering and Technology

Vol. 2, Issue 8, August 2015

$$
\begin{aligned}
& {\left[\begin{array}{l}
\log \left(E_{s}\right)=3.250-0.89 \log \left(D C P_{60^{\circ}}\right) \\
\text { where, } \mathrm{E}_{\mathrm{s}} \text { is the subgrade elastic modulus } \\
\text { (in } \mathrm{MPa} \text { ) obtained from the deflections } \\
\text { measured using PHONIX FWD. } \\
\log \left(E_{s}\right)=3.653-1.17 \log \left(D C P_{60^{\circ}}\right) \\
\text { Where, } \mathrm{E}_{\mathrm{s}} \text { is the subgrade elastic }
\end{array}\right]} \\
& \text { (in MPa)backcalculated by PEACH sy stem. }
\end{aligned}
$$

- De Beer (1991) has prescribed the following equation. Subgrade Elastic Modulus

$$
(\mathrm{MPa})=1176 \times\left(D P_{60^{\circ}}\right)^{-1.082}
$$

Where, DCP value is in $\mathrm{mm} / \mathrm{blow}$.

- The following equations were prescribed by Chai and Roslie (1998):

Relationship between in-situ CBR and

$$
\text { DCP: } \mathrm{E}_{\mathrm{s}}=17.6(269 / \mathrm{DCPV})^{0.64}
$$

Based on back-calculated results:

$$
\mathrm{E}_{\mathrm{s}}=2224(\mathrm{DCPV})^{-0.996}
$$

Where, Es = Subgrade modulus value (in MPa) and DCPV $=$ blows $/ 300 \mathrm{~mm}$ penetration of cone having apex angle $60^{\circ}$

- Chen et al (1999) conducted FWD, CBR and DCP tests on six sections of pavements in Kansas. Based on FWD back-calculated subgrade moduli $\left(\mathrm{E}_{\mathrm{s}}\right)$ and DCP test data, the following expression was prescribed.

Subgrade Resilient Modulus

$$
\left(\mathrm{E}_{\mathrm{s}} \text { in } \mathrm{MPa}\right)=338 \times\left(\mathrm{DCP}_{60^{\circ}}\right)^{-0.3}
$$

Where, $D C P_{60^{\circ}}$ value was in the range of 60 to 10 $\mathrm{mm} /$ blow.

Chen et al (1999) found that the subgrade moduli determined from relationships between DCP to CBR and $\mathrm{CBR}$ to $\mathrm{E}_{\mathrm{s}}$ were widely varying along the length of the test sections.

- George and Uddin (2000) developed the following equations (Cited in Roy 2007).

For fine grained soils:

$$
\log \left(E_{s} \text { in } M P a\right)=2.726-0.492 \log \left(D C P_{60^{0}}\right)
$$

For coarse grained soils:

$$
\log \left(E_{s} \text { in } M P a\right)=2.372-0.475 \log \left(D C P_{60^{\circ}}\right)
$$

- Chen et al (2005) prescribed the following equation (After eliminating outlier data).

$$
E_{s}=537.76 \times\left(D C P_{60^{\circ}}\right)^{-0.6645}(28)
$$

Where, $\mathrm{E}_{\mathrm{s}}=$ Granular Layer Resilient Modulus (MPa)

- As an indirect approach, Siekmeier et al (2000) and Chen et al $(2001,2005)$, converted the DCP index value to CBR value by using the equation developed by Webster et al (1992) and the obtained CBR value is converted into the resilient modulus (Es) value using the following equation of TRL-UK (Lister and Powell 1987).
Subgrade resileint modulus

$$
\left(E_{s} \text { in } M P a\right)=17.6 \times C B R^{0.64}
$$

Chen et al (2001) conducted a series of FWD and DCP tests on base and subgrade layers of two pavement sections in Texas. The test results were found to be satisfactorily comparable. However, they found that the DCP index values can be affected by at least 10 percent due to variations in the test procedure.

- Several attempts were also made in India (Sood et al 1996, Srinivasa et al 2003, 2006), USA (Mi-DOT) and other parts of the world (Livneh et al 2000) for developing equations to estimate of modulus value of granular and subgrade soil using DCP index value and material parameters such as field density, density ratio, liquid limit, plasticity index, coefficient of uniformity, field moisture content, ratio between field to OMC and percent soil passing different sizes of sieves.

In addition to this, there are several relationships available for determining (i) AASHTO granular layer coefficients (cited in Roy 2007), (ii) unconfined compressive strength (UCS) of soil (De Villiers 1980; McElvaney and Djatnika 1991), using DCP test values of granular base and subbase and (iii) shear strength of cohesion less materials using relationships available between the laboratory determined values of $\mathrm{DCP}_{60}{ }^{\circ}$ and triaxial deviator stress at failure (Ayers et al 1989).

\section{V.STRUCTURAL EVALUATION OF PAVEMENTS}

As a part of a research project in India, Falling Weight Deflectometer (FWD) and Dynamic Cone Penetrometer (DCP) tests were conducted on different sections of National Highway (NH) 6, National Highway (NH) 60, Salua Road and IIT-perimeter Road. The above tests were conducted during post monsoon season because during this period the subgrade becomes soft or less stiff due to accumulation of rain and stagnated water.

NH 6 and NH 60 are two-lane highways. On NH 6, six different pavement stretches of about $300 \mathrm{~m}$ length each were selected and the type of subgrade soils ranged from clay to silt. The types of subgrade soil encountered at $\mathrm{NH}$ 60 are of clay to silty clay. Traffic volumes on Salua road and IIT-perimeter road are lower. Soil sample collected from one test pit excavated in Salua road indicated the subgrade soil as clay type. Along the IIT-perimeter road, the soil type varied from clay to silt.

\section{A. Deflection Measurements Using Falling Weight} Deflectometer

Pavement deflection measurements on selected test sections were taken using FWD (Srinivasa 2001). An impulse load of $40 \mathrm{kN}$ in magnitude was applied over a contact area of radius $150 \mathrm{~mm}$. The FWD loading time ranges between 25 to 30 milli-seconds as usually. A load cell was used to measure the impulse load. Six geophones/deflection sensors were used to measure surface deflection basin and the sensors were placed radially at $300 \mathrm{~mm}$ intervals from the center of the loading plate. 


\section{B. Analysis of FWD Data}

Effective layer moduli were back calculated using a Genetic Algorithm based back-calculation computer program, BACKGA (Murthy 1999). A linear elastic layered system, ELAYER program (Reddy 1993), was used for forward calculation routine of the BACKGA program. All the FWD tested pavement sections were modeled as 3 layer system.

\section{DCP and CBR Tests}

DCP tests were conducted on subgrade soil of the pavement sections tested with FWD. Soil samples were collected from some of the sections and were tested in laboratory for determination of their CBR values and soil classification.

The details of subgrade soil classification, DCP, FWD and CBR test results are given in Table 2-5.

D. Development of Regression Models

Regression analysis was carried out on the data collected in the present investigation and trials were made to develop different forms of relationships between the values of (a) $\mathrm{CBR}$ and $\mathrm{DCP}_{60}{ }^{\circ}$ and (b) back-calculated subgrade modulus $\left(\mathrm{E}_{\mathrm{s}}\right)$ and $\mathrm{DCP}_{60}{ }^{\circ}$. From the trials, the following models were found to be the most suitable.

$$
\begin{aligned}
& \text { Between } \mathrm{CBR} \text { and } \mathrm{DCP}_{60}{ }^{\circ}: \\
& \log \left(C B R_{s} \text { in per cent }\right)= \\
& 2.71545-1.3152 \log \left(D C P_{60^{\circ}}\right) \\
& \left(\mathrm{N}=32, \mathrm{R}^{2}=0.99\right)
\end{aligned}
$$

Between $\mathrm{E}_{\mathrm{s}}$ and $\mathrm{DCP}_{60}$ :

$$
\begin{aligned}
& \log \left(E_{s} \text { in } M P a\right)=2.553-0.6438 \log \left(D C P_{60^{\circ}}\right) \\
& \left(\mathrm{N}=96, \mathrm{R}^{2}=0.71\right)
\end{aligned}
$$

\section{COMPARATIVE STUDY}

Comparative studies were conducted using the relationships developed in the present study with similar relationships available from the literature review. The Comparative study considered two types of relationships between (i) $\mathrm{CBR}$ and $\mathrm{DCP}_{60}{ }^{\circ}$ and (ii) $\mathrm{E}_{\mathrm{s}}$ and $\mathrm{DCP}_{60}{ }^{\circ}$.

(i) On relationships between $\mathrm{CBR}$ and $\mathrm{DCP}_{60}{ }^{\circ}$

Relationships between $\mathrm{DCP}_{60}{ }^{\circ}$ and $\mathrm{CBR}$ values are presented in Figure 3. It is noted that, all the lines of the relationships are relatively located closer within a narrow bandwidth except the relationships prescribed by McElvaney et al (1985) and Nazzal (2003). Such disparities among relationships which were developed in different countries may be due to slight variations in the test procedure, differences in the soil moisture content, compacted density, surrounding confinement and type of soil. It is also noted that, all above equations are acceptable to the in-situ conditions prevailing and based on the adopted test conditions.

Further comparison has been made on the relationships of fine grained soils and other which were developed by Harison (1989), TRL-UK (1990), Webster et al (1992) and the Author. It can be observed from the Figure 4 that, (a) the relationships (by Eq. 6 and 7) developed by Harison are showing almost same slope (or trend) for the soil strength considered (b) The relationships of TRL-UK, Harrison and by the present study are closely matching with each other except with small differences (c) at the lower values of CBR, all the relationships are within a close bandwidth except the relationships (by Eq. 12 and 13) developed by Webster et al (1992) which were specifically prescribed for soil types of CL (where CBR $<10$ per cent) and $\mathrm{CH}$. This indicates that, the $\mathrm{DCP}_{60}{ }^{\circ}$ values are sensitive at smaller $\mathrm{CBR}$ values and the subgrade consists of highly plastic clay.

(ii) On relationships between $\mathrm{E}_{\mathrm{s}}$ and DCP:

Relationships between back-calculated subgrade modulus $\left(\mathrm{E}_{\mathrm{s}}\right)$ and $\mathrm{DCP}_{60}{ }^{\circ}$ are presented in Figure 5. Larger variations are found among these relationships. A line drawn based on indirect method using relationships of Webster et al (1992) (by Eq 10) and TRL-UK (Lister and Powell 1987) (by Eq 28) is found to be located in the middle of the lines. Such scatter and disparities are not abnormal because, in different countries the subgrade soil properties may vary with many parameters such as variations in moisture content, intensity of compaction took place during construction and traffic loading, surrounding confinement and drainage conditions. It is also noted that, all above equations are acceptable which are derived based on the test conditions and prevailing material properties.

\section{CONCLUDING REMARKS}

The task of selection of appropriate values of subgrade strength for the analysis of new as well as in-service pavements has been engaging the attention of pavement researchers for a number of years. Towards this objective, the DCP as a low cost and alternative tool used for evaluating unbound granular and subgrade soil of low volume and roads in developing and under-developed countries where routine evaluation of FWD is not feasible. The relationships available are useful for estimation of soil strength properties used for design and structural evaluation of unbound granular/soil layers of pavement. The disparities among the different relationships developed for different countries may be due to variations in prevailing soil type, drainage condition, layers confinement, depth of testing and variations in test procedures adopted. However, the available relationships are acceptable which were derived based on test procedure adopted and prevailing soil properties.

\section{ACKNOWLEDGEMENT}

The Author is thankful to Prof. D. Venkateshwar Rao, Professor of Civil Engineering, Consultant for dam safety organization -Irrigation Dept the Govt. of Andhra Pradesh \& Formerly Consultant - Commonwealth Secretariat, London, CFTC; Sri Jaswant Kumar, Chief Engineer, $\mathrm{R} \& \mathrm{~B}$, for providing necessary suggestions and grateful to his teachers, Prof. B. B. Pandey, Rtd., Professor, Prof. M. Majumdar (Late) Rtd., Professor and Prof. K. Sudhakar Reddy, Professor of Civil Engineering, IIT, Kharagpur, India, for imparting basic training input. 


\section{REFERENCES}

[1] Ayers M. E., Thompson M. R. and Uzarski D. R., 1989, "Rapid Shear Strength Evaluation of In-Situ Granular Materials," Transportation Research Record No. 1227, TRB, Washington, D.C., pp.134-146.

[2] Chai G. and Roslie N., 1998, "The Structural Response and Behavior Prediction of Subgrade Soils Using Falling Weight Deflectometer in Pavement Construction," Proc., of $3^{\text {rd }}$ Int. Conf. on Road and Airfield Pavement Technology.

[3] Chen D. H., Lin D. F., Liau P. H. and Bilyen J., 2005, "A Correlation Between Dynamic Cone Penetrometer Values and Pavement Layer Moduli," Geotechnical Testing Journal, Vol. 28(1), pp.42-49.

[4] Chen D. H., Wang J.N., and Bilyen J., 2001, "Application of Dynamic Cone Penetrometer in Evaluation of Base and Subgrade Layers," Transportation Research Record 1764, TRB, Washington, D. C., pp.1-10.

[5] Chen J., Hossain M. and Latorella T. M., 1999, "Use of Falling Weight Deflectometer and Dynamic Cone Penetrometer in Pavement Evaluation," Transportation Research Record No.1655, TRB, Washington, D. C., pp.145-151.

[6] Chua K. M. and Lytton R. L., 1988, "Dynamic Analysis Using The Portable Pavement Dynamic Cone Penetrometer," Transportation Research Record No. 1192, TRB, pp.27-38.

[7] De Beer M., 1991, "Use of the Dynamic Cone Penetrometer (DCP) in the Design of Road Structures." Geotechnics in the African Environment, Vol. 1, Blight et al. (Eds), Balkema, Rotterdam, pp.167-183.

[8] De Villiers P. J., 1980, Dynamic Cone Penetrometer Correlation with Unconfined Compressive Strength, Univ. of Pretoria, Pretoria, 1980.

[9] Ese D., Myre J., Noss P. and Vaernes E., 1994, "The Use of Dynamic Cone Penetrometer (DCP) for Road Strengthening Design in Norway," Proc., the $4^{\text {th }}$ Int., Conf., on the Bearing Capacity of Roads and Airfields, pp.343-357.

[10] Ese D., Myre J., Noss P. and Vaerness E., 1994, "The Use of the Dynamic Cone Penetrometer (DCP) for Road Strengthening Designs in Norway," Proc., of $4^{\text {th }}$ Int. Conf., on the Bearing Capacity of Roads and Airfields, Univ. of Minnesota, Minneapolis, Mn., pp.3-22.

[11] Ford G. R. and Eliason B. E., 1993, "Comparison of Compaction Methods on Narrow Surface Drainage Trenches," Transportation Research Record No. 1425, Transportation Research Board, Washington, D.C., pp.18-27.

[12] Gabr M. A., Hopkins K., Coonse J. and Hearne T., 2000, "DCP Criteria for Performance Evaluation of Pavement Layer," Journal of Performance of Constructed Facilities, ASCE, Vol.14(4), pp.141148.

[13] Grogan W. P. and Tingle J. S., Evaluation of Un surfaced Airfield Criteria for Operation of C-17 Aircraft, J1. of Transportation Engineering, ASCE, Vol. 125(1), 1999.

[14] Harison J. A., 1989, "In Situ CBR Determination by DCP Testing Using a Laboratory-based Correlation," Australian Road Research, Vol. 19(4), pp.313-317

[15] IRC:SP:72-2007, 2007, "Guidelines for the Design of Flexible Pavements for Low Volume Rural Roads," The Indian Roads Congress, New Delhi, India.

[16] Jayawickrama P. W., Amarasiri A. L. and Regino P. E., 2000, "Use of Dynamic Cone Penetrometer to Control Compaction of Granular Fill," Transportation Research Record No. 1736, TRB, Washington, D.C.

[17] Kleyn E. G. and Savage P. E., 1982, "The Application of the Pavement DCP to Determine the Bearing Properties and Performance of the Road Pavements," Int. Symposium on Bearing Capacity of Roads and Airfields, Trodheim, Norway, pp.238-246.

[18] Kleyn E. G. and van Heerden M. J. J., 1983, Using DCP Soundings to Optimise Pavement Rehabilitation, Paper submitted for Annual Transportation Convention, Johannesburg, Report LS/83, Materials Branch, Transvaal Roads Dept., Pretoria, South Africa, July.

[19] Kleyn E. G., 1975, The Use of the Dynamic Cone Penetrometer (DCP), Report No. 2/74, Transvaal Roads Department, Pretoria, South Africa, July.

[20] Kleyn E. G., Van Heerden M. J. J. and Rossouw A. J., 1982, “An Investigation to Determine the Structural Capacity and Rehabilitation Utilization of a Road Pavement Using the Pavement
Dynamic Cone Penetrometer," Int. Symposium on Bearing Capacity of Roads and Airfields, Trodheim, Norway, pp.10111026.

[21] Kleyn, E. G., Maree, J. F. and Savage, P. F., 1982, "The Application of a Portable Pavement Dynamic Cone Penetrometer to Determine In-Situ Bearing Properties of Road Pavement Layers and Subgrades in South Africa," The European Symposium on Penetration Testing, Amsterdam, Netherlands, pp.277-282, May.

[22] Lister N. W. and Powell W. D, 1987, "Design Practice for Bituminous Pavements in the United Kingdom". Proc. $6^{\text {th }}$ International Conference on Structural Design of Asphalt Pavements, Vol. 1, pp.220-231.

[23] Livneh M. and Ishai I., 1987, "Pavement and Material Evaluation by a Dynamic Cone Penetrometer," Proc., 6th International Conference on Structural Design of Asphalt Pavements, Vol. 1, Ann Arbor, Michigan, 665-674.

[24] Livneh M. and Livneh N. A., 1994, "Subgrade Strength Evaluation with the Extended Dynamic Cone Penetrometer," Proc., $7^{\text {th }}$ Int., Congress Int., Association of Engineering Geology, Vol. 1, Lisbon.

25] Livneh M. Livneh N. A. and Ishai I., 2000, "The Israeli Experience with the Regular and Extended Dynamic Cone Penetrometer for Pavement and Subsoil-Strength Evaluation," Nondestructive Testing of Pavements and Backcalculation of Moduli: Vol. 3, ASTM STP 1375, S. D. Tayabji and E. O. Lukanen, Eds., ASTM, West Conshohocken, PA, pp.189-213.

[26] Livneh M., 1987, "Validation of Correlations between a Number of Penetration Tests and In-Situ California Bearing Ratio Tests", Transportation Research Record No. 1219, TRB, Washington, D.C., pp.56-67, 1987.

[27] Livneh M., 1991, "Verification of CBR and Elastic Modulus Values Derived from Local DCP Tests.” Proc., $9^{\text {th }}$ Asian Regional Conference on Soil Mechanics \& Foundation Engineering, Vol. 1, Bangkok, pp.45-50.

[28] Livneh M., Ishai I. and Livneh N. A., 1995, "Effect of Vertical Confinement on Dynamic Cone Penetrometer Strength Values in Pavement and Subgrade Evaluations," Transportation Research Record No. 1473, TRB, Washington, D.C., pp.1-8.

[29] McElvaney J. and Djatnika I., 1991, "Strength Evaluation of LimeStabilized Pavement Foundations Using the Dynamic Cone Penetrometer," Journal of ARRB, Vol. 21(1).

[30] McElvaney J., Jayaputra A. and Harison J., 1985, "Correlation of CBR and dynamic cone strength measurements of soils," Proceedings of 3rd Indonesian Conference on Geotechnics, Vol. 1, Jakarta.

[31] Murthy S. M, 1999, "Application of Genetic Algorithms in Pavement Engineering”, M. Tech. Thesis submitted to the Indian Institute of Technology, Kharagpur, India.

[32] Nazarian S., Tandon V., Crain K. and Yuan D., 2000, "Use of Instrumented Dynamic Cone Penetrometer in Pavement Characterization," Nondestructive Testing of Pavements and Backcalculation of Moduli: Vol. 3, ASTM STP 1375, S. D. Tayabji and E. O. Lukanen, Eds., ASTM, West Conshohocken, PA, pp.214228.

[33] Nazzal M. D., 2003, "Field Evaluation of In-Situ Test Technology For Qc/Qa During Construction of Pavement Layers And Embankments," A Thesis Submitted to the Louisiana State Univ. and Agricultural and Mechanical College.

[34] Pen C. K., An assessment of the available methods of analysis for estimating the elastic moduli of road pavements. Proc., $3^{\text {rd }}$ Int. Conf., on BCRA, Trondheim, 1990.

[35] Reddy K. S., 1993, "Analytical Evaluation of Bituminous Pavements", Ph.D. thesis, Civil Engineering Department, IIT, Kharagpur, India.

[36] Roy B. K., New Look at DCP Test with a Link to AASHTO SN Concept, Jl. of Transportation Engineering, ASCE, Vol. 133(4), pp.264-274, 2007

[37] Scala A. J., 1956, "Simple Methods of Flexible Pavement Design Using Cone Penetrometers," New Zealand Engineering, Vol. 11(2), pp.34-44.

[38] Scala A. J., 1956, "Simple Methods of Flexible Pavement Design Using Cone Penetrometers," Proc., $2^{\text {nd }}$ Australian-New Zealand Conf Soil Mech. and Foundation Eng, pp.73.

[39] Siekmeier J., Burnham T. and Beberg D., 1998, “Mn/DOT's New Base Compaction Specification Based on the Dynamic Cone Penetrometer," $46^{\text {th }}$ Geotechnical Engineering Conference, Univ, of Minnesota, Feb. 
[40] Siekmeier J., Young D. and Beberg D., 1999, "Use of DCP and portable FWD for subgrade characterization in Minnesota," Proc., $3^{\text {rd }}$ Symposium on Nondestructive Testing of Pavements and Backcalculation of Moduli, SPT 1375. 1999.

[41] Siekmeier J., Young D. and Beberg D., 2000, "Comparison of the Dynamic Cone Penetrometer with other tests During Subgrade and Granular Base Characterization in Minnesota," Nondestructive Testing of Pavements and Backcalculation of Moduli: $3^{\text {rd }}$ Volume, ASTM SPT 1375., S. D. Tayabji and E. O. Lukanen, Eds.

[42] Smith R. B. and Pratt D. N., 1983, "A Field Study of In-situ California Bearing Ratio and Dynamic Cone Penetrometer Testing for Road Subgrade Investigations," Australian Road Research, ARRB, Vol. 13(4), pp.285-294, December, 1983.

[43] Sood, V. K., Vijayaraghavan, S. R., Joshi, P., Rao, Y. V. and Kannan S., 1996, "Evaluation of in-situ subgrade strength by dynamic cone Penetrometer". Indian Roads Congress, Highway Research Board, No. 55, pp.39-49.

[44] Srinivasa K. R., 2001, "Structural Evaluation of Pavements Using Falling Weight Deflectometer", Ph.D. thesis, Civil Engineering Department, IIT, Kharagpur, India.

[45] Srinivasa K. R., Ajay Kumar and Subba Rao, 2006, "Fabrication of DCP For Evaluation of Subgrade Soil", National Conference on Civil Engineering Systems, Department of Civil Engineering, Osmania University, Hyderabad, 1-3 June.
[46] Srinivasa, Kumar, R., Reddy K. S., Mazumdar M. and Pandey B. B., 2003, "Models for Estimation of Subgrade Moduli from DCP Tests," The International Journal of Pavement Engineering \& Asphalt Technology, UK, Vol. 4 (2), December.

[47] Srinvasa, Kumar. R., 2009, A Text Book of Highway Engineering, under publication.

[48] TRL, 1990, Transport Research Lab., A Users Manual for a Program to Analyse Dynamic Cone Penetrometer Data, Overseas Rd. Note 8, Dept., of Transport, UK.

[49] Van Vuuren, 1969, "Rapid Determination of CBR with the Portable Dynamic Cone Penetrometer," Reprint from the "The Rhodesign Engineer", September.

[50] Webster S. L., Brown R. W. and Porter J. R., 1994, "Force Projection Site Evaluation Using the Electrical Cone Penetrometer (ECP) and the Dynamic Cone Penetrometer (DCP)," Proc., of $4^{\text {th }}$ Int. Conf., on the Bearing Capacity of Roads and Airfields, Univ. of Minnesota, Minneapolis, Mn.

[51] Webster S. L., Grau R. H. and Williams T. P., 1992, "Description and Application of Dual Mass Dynamic Cone Penetrometer," Instruction Report, GL-92-3, Army Engineers Waterways Experiment Station, Vicksburg, Miss.

52] Zhang Z. J., Abu-Farsakh Y. M. and Wang L., 2004, "Evaluation of Trench Backfill at Highway Cross-Drain Pipes", Submitted to $83^{\text {rd }}$ Transportation Research Board Annual Meeting, Washington, D. C.

TABLE 1-Relationships between $\mathrm{DCP}_{\theta}{ }^{\circ}$ and CBR Values (from Srinivasa, 2009).

\begin{tabular}{|c|c|c|}
\hline Reference/Developed/Source & Equation $^{b}$ & Equation Number \\
\hline Kleyn and Van Heerden 1983 & $\log _{10} \mathrm{CBR}=2.632-1.28 \log _{10}\left(\mathrm{DCP}_{60^{\circ}}\right)$ & 2 \\
\hline $\begin{array}{l}\text { Smith and Pratt } 1983 \\
\text { (Developed for ARRB) }\end{array}$ & $\log _{10} \mathrm{CBR}=2.555-1.145 \log _{10}\left(\mathrm{DCP}_{60^{\circ}}\right)$ & 3 \\
\hline McElvaney et al 1985 & $\log _{10} \mathrm{CBR}=2.81-1.32 \log _{10}\left(\mathrm{DCP}_{60^{\circ}}\right)$ & 4 \\
\hline Livneh and Ishai 1987 & $\log _{10} \mathrm{CBR}^{\mathrm{F}}=2.2-0.71\left(\log _{10}\left(\mathrm{DCP}_{30^{\circ}}\right)\right)^{1.5}$ & 5 \\
\hline \multirow{2}{*}{ Harison (1989) } & $\begin{array}{c}\text { For } \mathrm{DCP}_{60^{\circ}} \geq 10 \mathrm{~mm} / \text { blow: } \\
\log _{10} \mathrm{CBR}=2.56-1.16 \log _{10}\left(\mathrm{DCP}_{60^{\circ}}\right)\end{array}$ & 6 \\
\hline & $\begin{array}{c}\text { Or For } \mathrm{DCP}_{60^{\circ}}<10 \mathrm{~mm} / \text { blow: } \\
\log _{10} \mathrm{CBR}=2.54-1.12 \log _{10}\left(\mathrm{DCP}_{60^{\circ}}\right)\end{array}$ & 7 \\
\hline TRL, Road Note 81990 & $\log _{10} \mathrm{CBR}=2.48-1.057 \log _{10}\left(\mathrm{DCP}_{60^{\circ}}\right)$ & 8 \\
\hline $\begin{array}{c}\text { Livneh, } 1991 \\
\text { (Was obtained by substituting } \\
\text { Eq.1 in Eq. 5) }\end{array}$ & $\log _{10} \mathrm{CBR}=2.2-0.71\left[\log _{10}\left(1.1 \times \mathrm{DCP}_{60^{\circ}}\right)\right]^{1.5}$ & 9 \\
\hline $\begin{array}{c}\text { Webster et al, 1992; The } \\
\text { Relationship developed for the US } \\
\text { Corps of Engineers }\end{array}$ & $\begin{array}{c}\text { Overall correlative relationship: } \\
\log _{10} \mathrm{CBR}=2.465-1.12 \log _{10}\left(\mathrm{DCP}_{60^{\circ}}\right)\end{array}$ & 10 \\
\hline Ese et al 1994 & $\log _{10} C B R=2.438-1.065 \log _{10}\left(\mathrm{DCP}_{60^{\circ}}\right)$ & 11 \\
\hline \multirow[b]{2}{*}{ Webster et al 1994} & For $\mathrm{CH}$ soil: $\log _{10} \mathrm{CBR}=2.542-1.0 \log _{10}\left(\mathrm{DCP}_{60^{\circ}}\right)$ & 12 \\
\hline & $\begin{array}{c}\text { For CL soil having CBR<10\%: } \\
\log _{10} \mathrm{CBR}=3.538-2.0 \log _{10}\left(\mathrm{DCP}_{60^{\circ}}\right)\end{array}$ & 13 \\
\hline Livneh et al 1995 & $\log _{10} \mathrm{CBR}^{\mathrm{F}}=2.14-0.69\left(\log _{10}\left(\mathrm{DCP}_{60^{\circ}}\right)\right)^{1.5}$ & 14 \\
\hline Nazzal (2003) & $\mathrm{CBR}=1.04+2559.44 /\left(-7.35+\mathrm{DCP}_{60^{\circ}}{ }^{1.84}\right)^{\mathrm{c}}$ & 15 \\
\hline $\begin{array}{c}\text { Coonse (1999) at North Carolina } \\
\text { State University (Cited in Roy 2007) }\end{array}$ & $\log _{10} \mathrm{CBR}^{\mathrm{f}}=2.53-1.14 \log _{10}\left(\mathrm{DCP}_{60^{\circ}}\right)$ & 16 \\
\hline
\end{tabular}

${ }^{\mathrm{b}} \mathrm{DCP}_{30^{\circ}}$ and $\mathrm{DCP}_{60^{\circ}}$ are the penetration values in $\mathrm{mm} / \mathrm{blow}$ where the cone apex angles are $30^{\circ}$ and $60^{\circ}$ respectively; $\mathrm{CBR}$ is the California Bearing Ratio (\%); $\mathrm{CBR}^{\mathrm{F}}$ indicates field $\mathrm{CBR}$; and $\mathrm{CBR}^{\mathrm{f}}$ indicates the field $\mathrm{CBR}$ value of cohesive residual soil. 
${ }^{c}$ the prescribed range of $\mathrm{DCP}_{60^{\circ}}$ value is 6.31 to $66.67 \mathrm{~mm} / \mathrm{blow}$.

TABLE 2-Test Results of IIT- Perimeter Road

\begin{tabular}{|c|c|c|c|c|}
\hline Test location at KM & DCP $(\mathrm{mm} / \mathrm{blow})$ & $\mathrm{E}_{\mathrm{s}}(\mathrm{MPa})$ & $\mathrm{CBR}(\%)$ & Soil Classification \\
\hline 4.000 & 36.20 & 42.50 & 4.60 & $\mathrm{~A}-2-6$ \\
\hline 3.985 & 37.50 & 43.60 & & \\
\hline 3.970 & 39.60 & 37.00 & & \\
\hline 3.955 & 40.10 & 35.70 & 4.00 & $\mathrm{~A}-2-6$ \\
\hline 3.940 & 38.80 & 37.50 & & \\
\hline 3.925 & 30.10 & 43.30 & & \\
\hline 3.910 & 33.40 & 41.30 & & $\mathrm{~A}-2-7$ \\
\hline 3.710 & 33.20 & 43.70 & 5.10 & $\mathrm{~A}-2-5$ \\
\hline 3.695 & 25.40 & 49.10 & 7.70 & \\
\hline 3.680 & 30.20 & 46.90 & 5.80 & $\mathrm{~A}-2-5$ \\
\hline 3.665 & 27.50 & 44.00 & & \\
\hline 3.650 & 28.50 & 44.40 & 6.30 & $\mathrm{~A}-2-4$ \\
\hline 3.400 & 14.00 & 69.40 & & \\
\hline 3.385 & 17.20 & 61.90 & & \\
\hline 3.370 & 13.20 & 72.00 & 17.40 & \\
\hline 3.355 & 12.10 & 68.60 & & \\
\hline 3.340 & 11.00 & 72.80 & & \\
\hline
\end{tabular}

TABLE 3 -Test Results of Salua road.

\begin{tabular}{|c|c|c|c|c|}
\hline Test location at KM & DCP $(\mathrm{mm} / \mathrm{blow})$ & $\mathrm{E}_{\mathrm{s}}(\mathrm{MPa})$ & $\mathrm{CBR}(\%)$ & Soil Classification \\
\hline 2.000 & 28.86 & 35.10 & 6.14 & A-2-6 \\
\hline 1.985 & 26.48 & 36.50 & & \\
\hline 1.970 & 26.52 & 45.50 & & \\
\hline 1.955 & 27.13 & 48.40 & & \\
\hline 1.940 & 29.50 & 39.90 & & \\
\hline 1.925 & 29.20 & 42.60 & 5.99 & A-2-6 \\
\hline 1.910 & 28.47 & 39.40 & & \\
\hline 1.895 & 31.47 & 39.10 & & \\
\hline 1.880 & 33.42 & 34.10 & & \\
\hline 1.865 & 32.86 & 38.30 & & \\
\hline 1.850 & 32.74 & 39.30 & & \\
\hline 1.835 & 32.62 & 39.20 & & \\
\hline 1.820 & 32.31 & 39.10 & & \\
\hline 1.805 & 32.65 & 35.20 & & \\
\hline 1.790 & 31.25 & 36.70 & & \\
\hline 1.775 & 32.41 & 36.10 & & \\
\hline 1.760 & 29.10 & 41.30 & & \\
\hline 1.745 & 29.36 & 37.40 & & \\
\hline
\end{tabular}

TABLE 4 -Test Results of National Highway 60.

\begin{tabular}{|c|c|c|c|c|}
\hline Test location at KM & DCP $(\mathrm{mm} / \mathrm{blow})$ & $\mathrm{E}_{\mathrm{S}}(\mathrm{MPa})$ & CBR $(\%)$ & Soil Classification \\
\hline 113.000 & 27.58 & 34.60 & & \\
\hline 112.985 & 26.13 & 41.00 & & \\
\hline 112.970 & 24.30 & 42.10 & & \\
\hline 112.955 & 25.21 & 48.50 & & \\
\hline 112.940 & 25.45 & 42.80 & & \\
\hline 112.925 & 28.50 & 38.90 & & \\
\hline 112.910 & 28.80 & 37.00 & & \\
\hline 112.895 & 29.10 & 37.60 & & \\
\hline 112.880 & 28.50 & 35.80 & & \\
\hline 112.780 & 33.20 & 31.20 & 4.85 & A-2-6 \\
\hline 112.765 & 29.60 & 35.90 & & \\
\hline 112.750 & 33.30 & 30.20 & & \\
\hline 112.735 & 30.60 & 33.70 & & \\
\hline
\end{tabular}


TABLE 5-Test Results of National Highway 6.

\begin{tabular}{|c|c|c|c|c|}
\hline Test location at KM & DCP (mm/blow) & $\mathrm{E}_{\mathrm{s}}(\mathrm{MPa})$ & CBR $(\%)$ & Soil Classification \\
\hline 123.000 & 27.50 & 47.00 & 7.00 & A-2-6 \\
\hline 122.995 & 18.63 & 62.70 & & \\
\hline 122.950 & 30.50 & 34.30 & & \\
\hline 122.945 & 19.60 & 62.00 & 10.15 & A-2-7 \\
\hline 122.845 & 20.80 & 54.80 & & \\
\hline 122.795 & 21.20 & 50.20 & & \\
\hline 122.745 & 30.00 & 41.70 & 5.85 & A-2-6 \\
\hline 124.000 & 20.02 & 54.30 & 10.00 & A-2-6 \\
\hline 123.900 & 25.20 & 36.10 & & \\
\hline 123.850 & 25.00 & 43.50 & & \\
\hline 123.845 & 25.30 & 36.20 & 7.95 & A-2-6 \\
\hline 123.795 & 31.52 & 36.00 & 5.65 & A-7-6 \\
\hline 123.745 & 31.00 & 38.10 & & \\
\hline 134.800 & 29.20 & 47.40 & 6.00 & A-7-6 \\
\hline 134.815 & 23.00 & 56.80 & & \\
\hline 134.830 & 24.04 & 56.20 & & \\
\hline 134.845 & 29.00 & 42.10 & 6.00 & A-2-6 \\
\hline 134.860 & 27.50 & 49.40 & 7.00 & A-6 \\
\hline 150.000 & 19.80 & 53.90 & 10.00 & A-2-6 \\
\hline 150.005 & 27.65 & 41.60 & & \\
\hline 150.180 & 18.60 & 52.20 & 11.00 & A-2-7 \\
\hline 150.185 & 22.65 & 48.50 & & \\
\hline 150.240 & 24.12 & 42.30 & & \\
\hline 150.245 & 23.64 & 45.80 & & \\
\hline 150.300 & 21.12 & 46.50 & & \\
\hline 150.305 & 21.22 & 46.90 & 9.70 & A-2-6 \\
\hline 151.000 & 20.22 & 49.80 & 9.97 & A-2-4 \\
\hline 151.005 & 24.36 & 41.90 & & \\
\hline 151.060 & 18.50 & 51.50 & 11.20 & A-2-6 \\
\hline 151.065 & 24.13 & 44.00 & & \\
\hline 151.120 & 26.90 & 41.50 & & \\
\hline 151.125 & 25.20 & 46.20 & & \\
\hline 151.240 & 22.70 & 48.00 & & \\
\hline 151.300 & 24.30 & 45.50 & & \\
\hline 151.305 & 18.60 & 52.60 & 11.00 & A-2-5 \\
\hline 152.000 & 26.00 & 44.50 & 7.80 & A-2-6 \\
\hline 152.060 & 18.50 & 59.00 & & \\
\hline 152.120 & 17.23 & 67.00 & 12.00 & A-2-6 \\
\hline 152.125 & 32.20 & 36.60 & 5.20 & A-2-6 \\
\hline 152.180 & 28.73 & 44.80 & & \\
\hline 152.240 & 27.59 & 47.90 & 6.80 & A-2-6 \\
\hline 153.350 & 17.53 & 51.30 & 11.50 & A-2-6 \\
\hline 153.355 & 15.97 & 55.90 & & \\
\hline 153.415 & 29.68 & 38.00 & 6.00 & A-2-6 \\
\hline 153.470 & 25.74 & 46.70 & & \\
\hline 153.535 & 27.13 & 40.70 & 6.90 & A-2-5 \\
\hline 153.590 & 27.20 & 41.00 & & \\
\hline 153.655 & 24.22 & 46.90 & & \\
\hline
\end{tabular}

\section{LIST OF FIGURE CAPTIONS}

FIG. 1-Details of DCP

FIG. 2-Different Methods of DCP Testing

(Modified and elaborated based on Livneh et al 2000)

FIG. 3-Relationships for Converting $\mathrm{DCP}_{60}$ to CBR (Srinivasa 2009)

FIG. 4-Comparison Between a Few Selected Relationships of $\mathrm{DCP}_{60}$ - CBR. 
FIG. 5-Relationships for Converting $\mathrm{DCP}_{60}$ to Elastic Modulus.

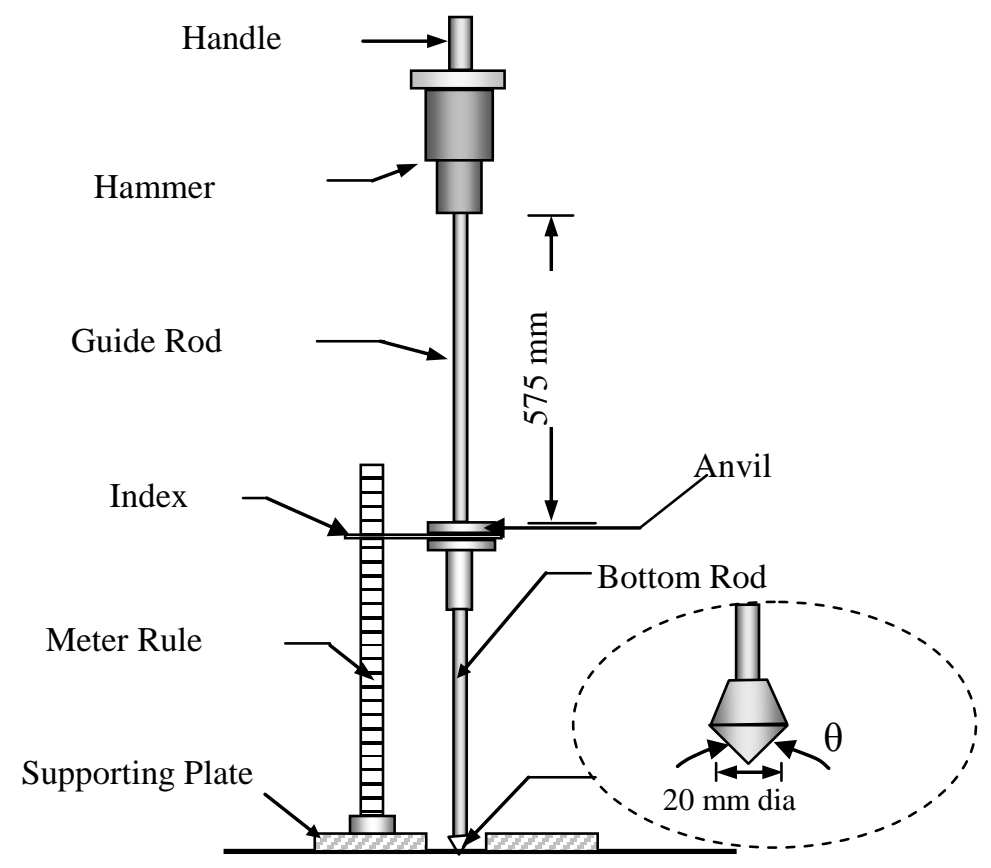

FIG. 1-Details of DCP.

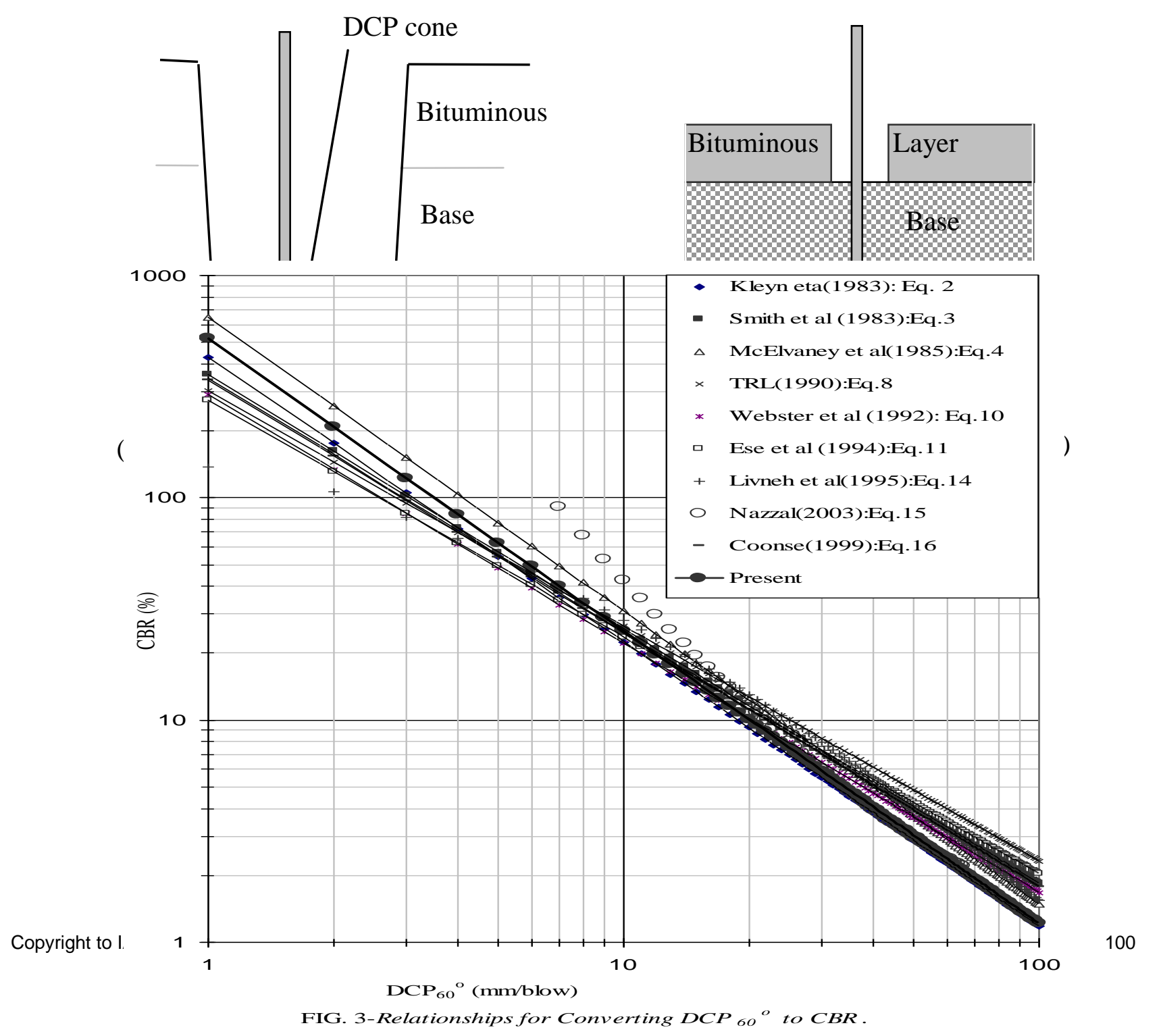




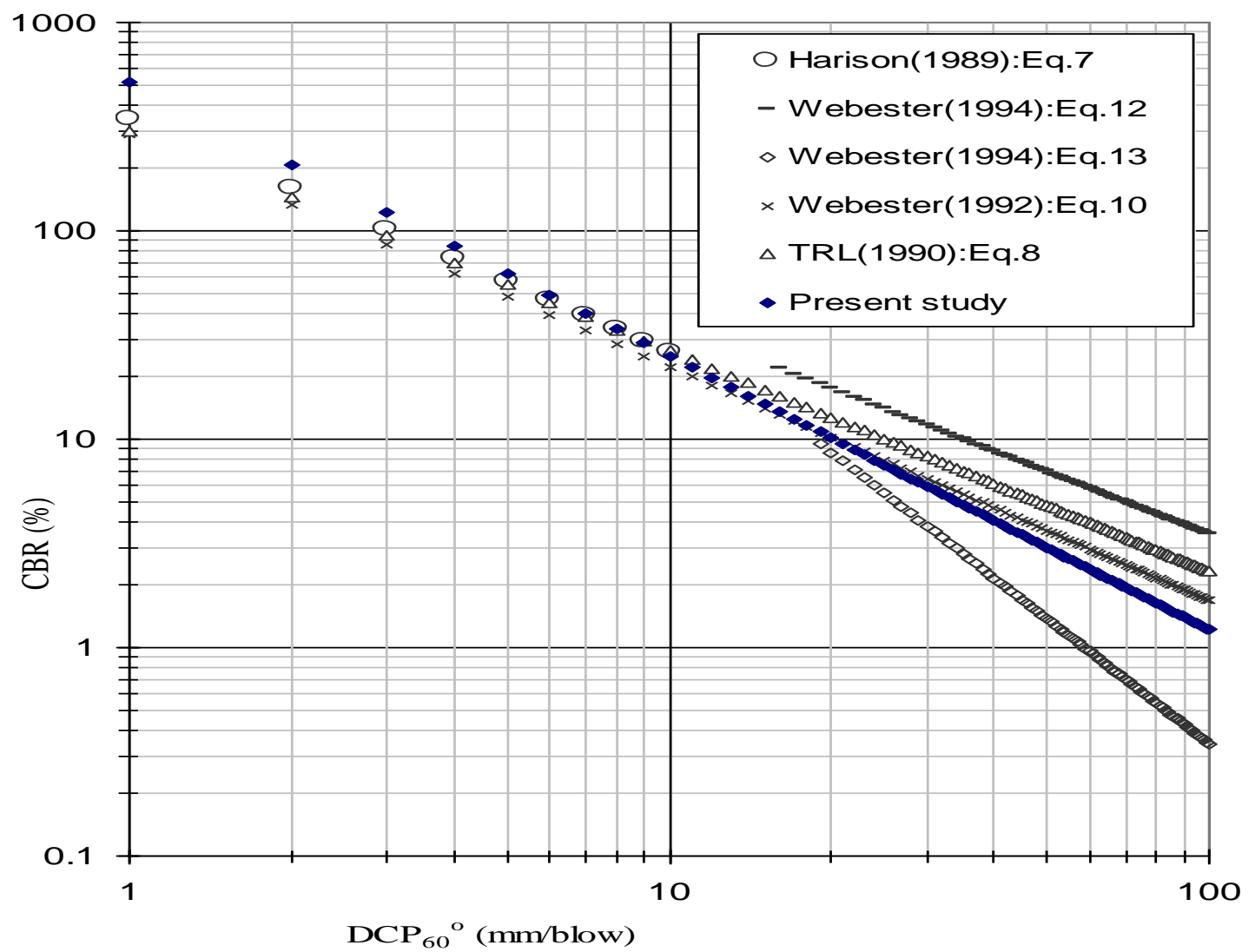

FIG. 4-Comparison Between a Few Selected Relationships of DCP ${ }^{\circ}{ }^{\circ}-\mathrm{CBR}$. 


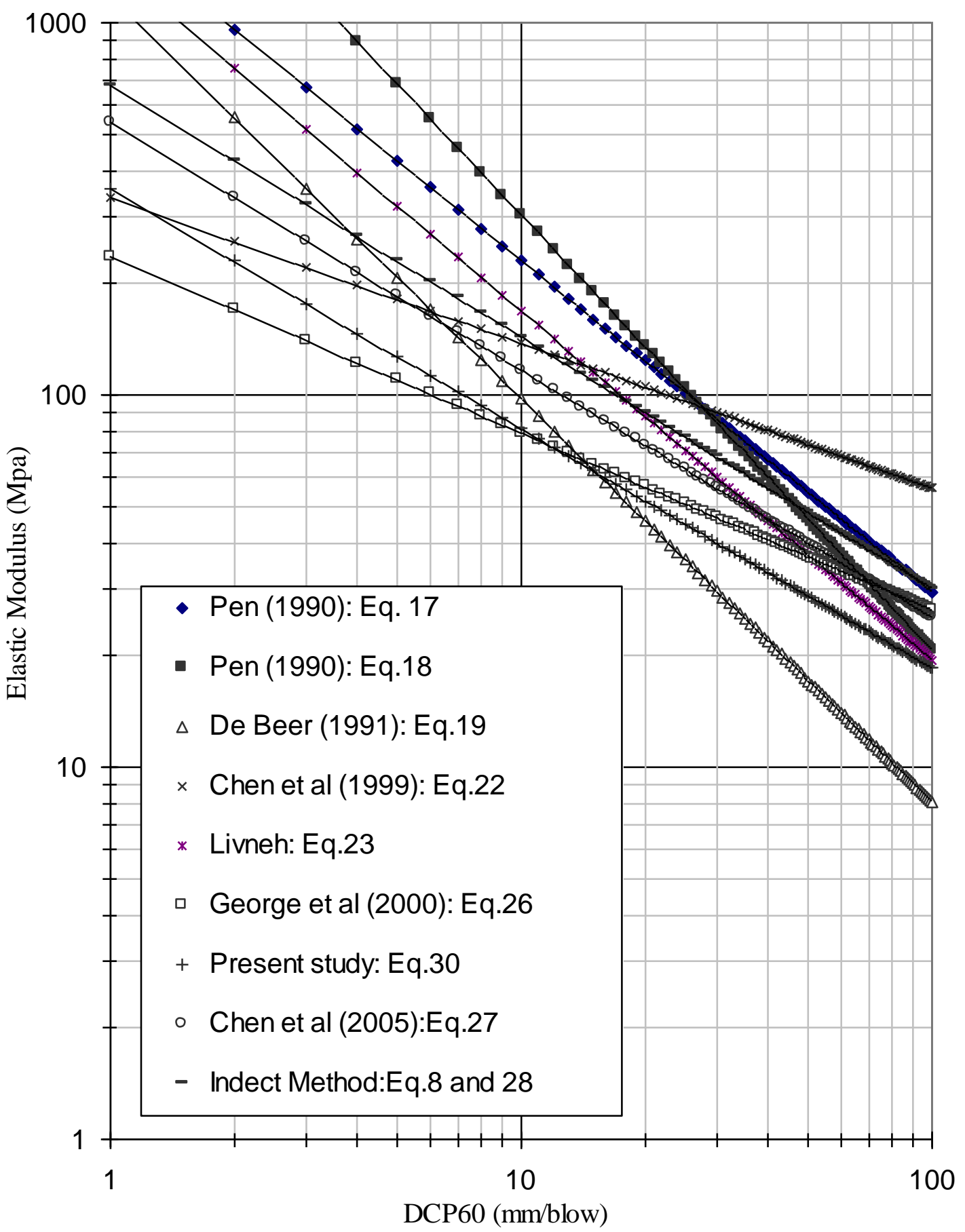

FIG.5-Relationships for Converting DCP 60 to Elastic Modulus. 